\title{
Implementasi Cara Hidup Jemaat Mula-mula dalam Kisah Para Rasul 2: 41-47 bagi Pertumbuhan Gereja Masa Kini
}

\author{
Andreas Sese Sunarko \\ Sekolah Tinggi Teologi El-Shadday, Surakarta, Jawa Tengah \\ andreassesesunarko@gmail.com
}

\begin{abstract}
The growth of church has been one of crucial issues that becomes a concentration point to church leaders, which is priestas the senior pastor or church council as the representative of local church members. The growth of church perceived as one of paramaters stating the existence of church to the people who are served as well as to other churches as ministry partner. The growth of church can be seen from two aspect is the quality of church members in terms of spiritual maturity reflected from the faith to God they whorship and in term of their daily behavior bringing positive impact. The other aspect is the quantity of church members from time to time. The growth of church can be achieved by the method or serving system that is believed by priest or church council to be implemented. In academic terminology, that method is also known as church growth system or method. They are many system or method of church growth. One of them is Cell Church system that is a system of naturaly growing church growth method with the starting point from the way of life the eraly church taken from Act 2:41-47. This idea, later on, can be implemented by today's churches is improving church growth.
\end{abstract}

Keywords: church growth; church lifestyle; early church; the Acts

\begin{abstract}
Abstrak
Pertumbuhan gereja menjadi salah satu isu penting yang terus menjadi konsentrasi bagi para pimpinan gereja, baik itu Pendeta sebagai Gembala Jemaat atau Majelis sebagai representasi jemaat lokal. Pertumbuhan gereja dinilai sebagai salah satu parameter eksistensi gereja tersebut dimata jemaat yang dilayaninya maupun dimata gereja-gereja lain sebagai mitra pelayanan. Pertumbuhan gereja bisa dilihat dari dua segi yaitu segi kualitas yang ditandai dengan kematangan jemaat atas nilai-nilai relegiositasnya yang terpancar dari tingkat keyakinannya terhadap pribadi Allah yang disembahnya dan terpancar dari perilaku sehari-harinya yang mendatangkan dampak positif. Adapun segi yang lain adalah segi kuantitas yang ditandai dengan pertumbuhan jemaat yang terlihat dari bertambahnya jumlah jemaat dari waktu ke waktu. Pertumbuhan gereja ini dapat terwujud dengan metode dan sistem pelayanan yang diyakini oleh Pendeta atau Majelis untuk diterapkan atau dalam dunia akademis disebut dengan metode atau sistem pertumbuhan gereja. Ada banyak metode atau sistem pertumbuhan gereja yang ada diantaranya metode atau sistem Gereja Sel, metode atau sistem pertumbuhan Gereja Modern dan lain sebagainya. Melalui tulisan ini penulis ingin menunjukan salah satu metode pertumbuhan gereja yang bertitik tolak pada cara hidup jemaat yang pertama sebagaimana dicatat dalam Kisah Para Rasul 2 : 41-47 yang nantinya dapat diterapkan oleh gereja-gereja masa kini dalam melakukan proses pertumbuhan gereja.
\end{abstract}

Kata kunci: cara hidup jemaat; jemaat mula-mula; Kisah Para Rasul; pertumbuhan gereja 


\section{PENDAHULUAN}

Memasuki era digital dan milineal, isu tentang pertumbuhan gereja masih menjadi isu yang relevan untuk dibicarakan, karena isu penting yang terus menjadi konsentrasi bagi para pimpinan gereja, baik itu Pendeta sebagai Gembala Jemaat atau Majelis sebagai representasi jemaat lokal. Pertumbuhan gereja dinilai sebagai salah satu parameter eksistensi gereja tersebut dimata jemaat yang dilayaninya maupun dimata gereja-gereja lain sebagai mitra pelayanan. Pertumbuhan gereja bisa dilihat dari dua segi yaitu segi kualitas yang ditandai dengan kematangan jemaat atas nilai-nilai relegiositasnya yang terpancar dari tingkat keyakinannya terhadap pribadi Allah yang disembahnya dan terpancar dari perilaku sehari-harinya yang mendatangkan dampak positif. Adapun segi yang lain adalah segi kuantitas yang ditandai dengan pertumbuhan jemaat yang terlihat dari bertambahnya jumlah jemaat dari waktu ke waktu.

Ada banyak metode atau teori pertumbuhan gereja yang bisa diterapkan untuk mewujudkan pertumbuhan gereja yang diharapkan, seperti gereja sel, pertumbuhan gereja alamiah dan lain sebagainya. Artikel ini bertujuan untuk menunjukkan cara hidup jemaat mula-mula dalam Kisah Para Rasul 2:41-47 yang dapat dijadikan salah satu metode atau sistem pertumbuhan gereja yang ideal. Pembahasan tentang jemaat mula-mula telah dibahas sebelumnya oleh Sonny Zaluchu, yang menyoroti cara hidup mereka sebagai ciri khas hidup iman Kristen. ${ }^{1}$ Harls Evan Siahaan sebelumnya telah menyotroti hal tersebut sebagai karakteristik Pentakostalisme yang dapat dikarakterisasi bagi kehidupan kekristenan masa kini. $^{2}$ Perhatian tentang jemaat mula-mula ini juga diteliti oleh Yushak Soesilo, yang menekankan pada pola kehidupan sosial mereka. ${ }^{3}$ Namun demikian dari ketiga pembahasan pada teks Kisah Para Rasul tersebut tidak mengaitkannya dengan pertumbuhan gereja.

Terkait isu pertumbuhan gereja, Joseph Chris Santo melihat pentingnya keteladanan sebagai faktor dalam pertumbuhan jemaat. ${ }^{4}$ Susanto Dwiraharjo ${ }^{5}$ dan Handreas Hartono menekankan kegiatan misi yang merupakan aktualisasi amanat agung sebagai faktor yang

\footnotetext{
${ }^{1}$ Sonny Eli Zaluchu, "Eksegesis Kisah Para Rasul 2:42-47 Untuk Merumuskan Ciri Kehidupan Rohani Jemaat Mula-Mula Di Yerusalem,” EPIGRAPHE: Jurnal Teologi dan Pelayanan Kristiani 2, no. 2 (2018): 72-82, accessed November 1, 2018, http://www.stttorsina.ac.id/jurnal/index.php/epigraphe.

${ }^{2}$ Harls Evan R. Siahaan, "Karakteristik Pentakostalisme Menurut Kisah Para Rasul," DUNAMIS ( Jurnal Teologi dan Pendidikan Kristiani ) 2, no. 1 (2017): 12-28, http://www.sttintheos.ac.id/ejournal/index.php/dunamis/article/viewFile/132/116.

${ }^{3}$ Yushak Soesilo, "Pentakostalisme Dan Aksi Sosial: Analisis Struktural Kisah Para Rasul 2:41-47," DUNAMIS: Jurnal Teologi dan Pendidikan Kristiani (2018).

${ }^{4}$ Joseph Christ Santo and Dapot Tua Simanjuntak, "Pengaruh Keteladanan Hidup Gembala Sidang Terhadap Pertumbuhan Gereja,” KHARISMATA: Jurnal Teologi Pantekosta 2, no. 1 (2019): 28-41.

5 Susanto Dwiraharjo, "Kajian Eksegetikal Amanat Agung Menurut Matius 28 : 18-20," Jurnal Teologi Gracia Deo 1, no. 2 (2019): 56-73, http://sttbaptisjkt.ac.id/e-journal/index.php/graciadeo.
} 
penting dalam pertumbuhan gereja. ${ }^{6}$ Artikel ini mencoba mengaitkan antara ciri khas jemaat mula-mula dalam Kisah Para Rasul sebagai faktor pertumbuhan gereja di masa kini. Gerakan pentakostalisme awal di Yerusalem telah menghasilkan perkembangan gereja yang signifikan hingga ke seluruh dunia.

\section{METODE PENELITIAN}

Metode penelitian dalam artikel ini adalah deskriptif analisis. Melalui pendekatan kualitatif literatur pada teks Kisah Para Rasul 4:41-47, cara hidup jemaat mula-mula dijadikan pola untuk meningkatkan pertumbuhan gereja di masa kini. Deskripsi tentang pertumbuhan gereja diuraikan sebagai bentuk yang ideal, baik menurut tokoh-tokoh ataupun mecontoh pola jemaat mula-mula di Kisah Para Rasul.

\section{Definisi Pertumbuhan Gereja}

Istilah pertumbuhan gereja dapat diartikan sebagai pengefektifan penyebaran Injil dan pelipatgandaan gereja-gereja di daerah yang baru. Sedangkan menurut anggaran dasar North America Society for Churh Growth yang dimaksud dengan pertumbuhan gereja adalah suatu disiplin ilmu yang menyelidiki sifat-sifat, perluasan, perintisan, pelipatgandaan, fungsi dan kesejahteraan gereja Kristen dalam hubungannya dengan penerapannya yang efektif dari Amanat Allah untuk menjadikan semua bangsa muridNya (Mat 28:18-20). ${ }^{7}$ Lebih lanjut disebutkan bahwa pertumbuhan gereja bukan suatu hal yang tiba-tiba terjadi di suatu tempat, juga bukan mencari tenaga yang berbakat dan cocok untuk menuai dengan sukacita di satu ladang yang menguning. Pertumbuhan adalah suatu hal yang dilakukan dengan segenap hati oleh sekelompok masa yang memberikan respon baik.

Pada dasarnya pertumbuhan gereja adalah pelayanan berdasarkan Alkitab yang di dorong oleh data dan strateginya. ${ }^{8}$ Pertumbuhan gereja dapat dimengerti juga sebagai pertumbuhan yang menyangkut segala sesuatu atau mencakup soal membawa orang-orang yang tidak memiliki hubungan dengan Kristus ke dalam persekutuan dengan Dia dan membawa mereka menjadi anggota gereja yang bertanggung jawab. Pada sisi lain, definisi inti atau esensial dari pertumbuhan gereja adalah suatu bidang studi yang menyelidiki sifat dasar, ekspansi, penanaman, pelipatgandaan fungsi dan kesehatan gereja dalam hubungannya dengan pelaksanaan Amanat Agung Yesus Kristus untuk memuridkan segala (Mat 28:10-20). ${ }^{9}$ Kegiatan misi yang berlandaskan pada amanat agung Yesus merupakan dasar kehidupan dan pertumbuhan gereja di segala zaman.

\footnotetext{
${ }^{6}$ Handreas Hartono, "Mengaktualisasikan Amanat Agung Matius 28 : 19-20 Dalam Konteks Era Digital," KURIOS (Jurnal Teologi dan Pendidikan Agama Kristen) 4, no. 2 (2018): 19-20, www.sttpb.ac.id/ejournal/index.php/kurios.

${ }^{7}$ Peter Wongso, Tugas Gereja dan Misi Masa Kini (Malang : SAAT,1999), 51

${ }^{8}$ Ibid, 52

${ }^{9}$ Dwiraharjo, "Kajian Eksegetikal Amanat Agung Menurut Matius 28 : 18-20."
} 
Ada implikasi penting yang dapat dikemukakan terkait uraian di atas, yakni: Pertama, secara operasional, pertumbuhan gereja adalah penginjilan yang intinya memenangkan orang berdosa, menuntunnya kepada Kristus, dan menjadikan sebagai anggota gereja. Kedua, secara esensial definisi inti dari pertumbuhan gereja mendekati pokok pertumbuhan gereja dan perspektif empiris. Di sini pertumbuhan gereja adalah suatu bidang ilmu yang harus dikaji dari segala aspek, dalam kaitannya dengan pelaksanaan Amanat Agung Yesus Kristus. Definisi ini secara khusus terfokus kepada menghasilkan pertumbuhan secara aktual, dengan adanya pertumbuhan jiwa baru sebagai bagian dari pertumbuhan ekspansi, eksestensi, kontinuitas, dan lintas budaya serta lokasi. ${ }^{10}$

Pertumbuhan gereja yang sehat dan terus menerus bersifat multidemensi. Rick Warren mendefinisikan pertumbuhan gereja sejati terdiri dari lima segi yaitu: Gereja bertambah akrab melalui persekutuan; gereja bertambah sungguh-sungguh melalui pemuridan; gerejagereja kuat melalui ibadah; gereja bertambah besar melalui pelayanan; gereja bertambah melalui penginjilan. ${ }^{11}$ Chris Marantika berpendapat, bahwa pertumbuhan gereja merupakan pekerjaan Allah Tri Tunggal. Allah Bapa merencanakan dan membentuk gereja didekatkan masa lampau, Allah Anak menebus dan menyucikan gereja dalam kebangkitanNya (Ef 1:413). Peranan bapa dan Anak telah selesai. Kini tinggalah lagi peranan Roh Kudus dalam menyelesaikan program Allah di masa kini menuju era Dia yang adil dan makmur. Jadi pribadi yang nerupakan dinamika sentral dalam pertumbuhan gereja masa kini adalah Roh Kudus. ${ }^{12}$ Roh Kuduslah penggerak dari semua kegerakan gereja di segala masa.

\section{Metoda atau Sistem Pertumbuhan Gereja}

Sebagaimana dikatakan di atas bahwa pertumbuhan gereja bukan suatu hal yang tibatiba terjadi di suatu tempat, juga bukan mencari tenaga yang berbakat dan cocok untuk menuai dengan sukacita di satu ladang yang menguning. Pertumbuhan adalah suatu hal yang dilakukan dengan segenap hati oleh sekelompok masa yang memberikan respon baik. Salah satu bentuk respon yang baik yang bisa dilihat adalah bagimana cara pemimpin gereja itu mengelola gerejanya untuk terus bertumbuh. Cara pengelolaan gereja agar bisa bertumbuh adalah dengan menggunakan metode atau sistem yang diyakini akan mampu mewujudkan harapannya yaitu pertumbuhan gereja itu sendiri. Pada bagian ini ditunjukkan secara singkat proses atau metode pertumbuhan gereja sel dan pertumbuhan gereja modern.

\section{Metode atau Sistem Gereja Sel}

Allah itu dinamis karena Dia adalah Allah yang hidup, Ia akan terus bergerak khususnya untuk memulihkan gerejaNya. Sebelum berakhirnya segala sesuatu atau sebelum

\footnotetext{
${ }^{10}$ Yakob Tomatala, Teologi Misi (Jakarta : YT Leadership Fondation,2003), 185-186

${ }^{11}$ Rick Warren, The Purpose Driven Church (Malang, Gandum Mas,2006),54-55

${ }^{12}$ Kornelius Sabat, Pertumbuhan Gereja (Yogyakarta : Charista Press, 2016), 7
} 
Tuhan Yesus datang yang kedua kali, Tuhan Yesus menjanjikan harus terjadi terlebih dahulu pemulihan (Kis 3:21). Salah satu pemulihan yang akan terjadi adalah pemulihan pengajaran dan penggembalaan di dalam gereja melalui kelompok-kelompok kecil. Ada beberapa tokoh gereja yang menanggapi kegerakan itu dan mengalami kedasyatan Allah. Mereka bergerak di dalam gerakan Allah dan Tuhan membawa mereka dalam kegerakan yang luar biasa.

Pertama, ada John Wesley menggerakan penginjilan dan pemuridan melalui kelompok kecil yang dinamakan "kelas". Dalam pelayanannya ia telah berhasil mengembangkan pelayanan melalui kelompok kecil menjadi 10.000 klas. Dalam perkembangan berikutnya hal ini adalah fondasi bagi ledakan kelompok sel modern. Kemudian ada David Yonggi Cho, Seoul-Korea Selatan, yang dalam perjuangannya mengembangkan gereja yang dipercayakan oleh Tuhan kepadanya, ia telah memperjuangkan untuk merintis kelompokkelompok kecil yang dinamakan cell group. Dalam perkembangannya, gereja yang dipimpinnya menjadi gereja yang terbesar di dunia. Tokoh berikut adalah Caesar Castellanos, dari Bogotta, Kolombia. Setela ia berkunjung ke gereja di Seoul-Korea Selatan yang digembalakan oleh david Yonggi Cho, Caesar Castellanos mulai mengembangkan kelompok sel dengan metode Group 12 (G-12). Antara tahun 1991-1994, kelompok sel yang diperjuangkan telah berkembang dari 70 kelompok sel menjadi 1200 kelompok sel. Dan pada tahun 1996 berkembang lagi menjadi 10.438 kelompok sel.

Ada tokoh yang bernama Sunday Adelaja, dari Kiev, Ukraina. Gereja yang digembalakannya merupakan salah satu dari sepuluh gereja penginjilan yang berkembang paling cepat di dunia. Dimulai dengan 7 orang pada tahun 1993, dengan menggunakan metoda G-12 berkembang menjadi lebih dari 17.000 jemaat dan 15 gereja satelit. Ada juga sebuah gereja di Solo yang bernama Gereja Bethel Indonesia Keluarga Allah, yang menerapkan sistem kelompok sel, dan telah mengalami peningkatan pertumbuhan gereja yang luar biasa dibandingkan sebelumnya. Dimulai tahun 1997 dengan metode kelompok sel, pada tahun 2005 berkembnag menjadi 1516 kelompok sel dan kurang lebih 15.000 jemaat yang beribadah. ${ }^{13}$ Ternyata fakta yang terlihat nyata adalah, bahwa pemimpin-pemimpin gereja yang mempraktikkan metode atau sistem gereja sel dengan sel grupnya menikmati hasil pertumbuhan jemaat yang luar biasa. Pastinya ada keunggulan dalam pertumbuhan gereja yang menerapkan komsel ini, yaitu adanya prinsip-prinsip dalam komsel yang mendorong terjadinya pertumbuhan jemaat baik secara kuantitas maupun kualitas.

Prinsip yang menonjol adalah kehidupan kelompok sel adalah perjumpaan dengan Yesus dan setiap anggota komsel harus mengalami pengalaman perjalanan dan hubungan pribadi dengan Yesus. Mengalami perjumpaan dengan Yesus bisa melalui tiga perjumpaan

\footnotetext{
${ }^{13}$ Dep. Komsel GBI Keluarga Allah, SOM Kelas-3 Aku Pasti Berbuah (Solo : Diisi Media Cetak ElShadday Media Production, tth), 4-5
} 
yaitu perjumpaan dengan kasiNya (love encounter) hal ini terlihat dalam perjamuan kudus. Selanjutnya perjumaan dengan kebenaranNya (truth encounter) dapat dialami melalui sharring Firman Tuhan dan yang terakhir perjumpaan dengan kuasaNya (power encounter) hal ini dapat dirasakan melalui doa bersama dan saling melayani. ${ }^{14}$

\section{Metode atau Sistem Gereja Modern}

Metode atau sistem gereja modern ini yang diyakini sebagai metode atau sistem gereja yang paling banyak dipraktikkan oleh para pemimpin gereja dewasa ini yakni metode atau sistem gereja yang dikelola atau dikerjakan dengan sistem manajemen modern dan para pelayanannya dituntut menjadi para pelayan yang profesional di bidangnya. Gereja yang menjalankan metode ini biasanya gereja yang telah siap dengan modal finansial dan modal sumber daya yang sangat profesional. Gereja-gereja seperti ini paling banyak ada di kotakota besar, ada gereja yang sudah punya gedung gereja sendiri tapi banyak yang masih menyewa atau kontrak di Mall atau Ruko.

Semua pelayanan ditata dengan relatif humanis dan rileks, hanya cara masuknya saja yang diatur sedemikian rupa agat tetap lancar dan kondusif. Tampilan ruangan dibuat meriah dengan lampu-lampu sorot yang terpasang dan sistem permainan cahaya yang diatur sedemikian rupa, gaya memuji dibuat sedikit menyerupai konser musik, para pemuji dan singers dan pemain musik tampil energik dan sebagainya. Tampilan hamba Tuhan juga sedikit modis tapi rileks, materi firman Tuhan disesuaikan dengan konteks atau kebutuhan jemaat.

Metode atau sistem gereja modern ini tidak ada salahnya apabila dijalankan dengan tetap berpedoman pada Firman Tuhan dan Etika Pelayanan. Namun dewasa ini ada beberapa kritikan terhadap pengelolaan gereja modern yang sedikit menyimpang dari Firman Tuhan dan Etika Pelayanan antara lain kurangnya gereja dalam menekankan proses penginjilan, sehingga ada kalanya jiwa-jiwa yang datang ke gereja tersebut bukan hanya penginjilan akan tetapi hasil dari perpindahan atau memindahkan jemaat orang lain dengan cara-cara yang kurang etis misalnya melakukan pembujukan dengan memberikan sembako, beasiswa dan fasilitas yang lain. Selain itu seringkali pengajaran yang diajarkan kurang alkitabiah tetapi lebih bersifat motivator.

Memang kita juga harus jujur bahwa tidak semua gereja modern ini jelek, hanya kita perlu memilah-milah. Gereja yang mau tetap eksis tetap harus terbuka dengan perubahan jaman, jadi tidak salah gereja tetap melakukan modernisasi dalam praktek pelayanan dan pengadaan sumber daya manusia dan sarana prasaranya akan tetapi gereja juga harus tetap berkiblat pada kebenaran alkitab sebagai kebenaran mutlak yang harus dijunjung tinggi.

\footnotetext{
${ }^{14}$ Daniel Sutoyo, Komunitas Kecil Sebagai Tempat Pembelajaran gaya Hidup Kristen (Solo : Jurnal Antusias , STT Intheos, Vol.II,2012), 11
} 
Gereja modern yang komitmen dengan hal ini maka akan menjadi gereja modern yang terus dipakai Tuhan dan memberkati banyak orang.

\section{Analisis Teks Kisah Para Rasul 2:41-47}

Penggunaan kitab Kisah Para Rasul sebagai dasar deskriptif dalam penelitian literatur ini merupakan hal yang umum, dikrenakan kitab inilah yang memperlihatkan munculnya gereja dan jemaat yang mula-mula atau gereja mula-mula sebelum akhirnya berkembang ke seluruh dunia. Kegiatan para rasul dikisahkan sedemikian rupa oleh Lukas dalam kitab ini untuk menunjukkan karakteristik dari kitab ini. Siahaan menyebutkan bahwa Kisah Para Rasul merupakan dasar teologi Pentakosta. ${ }^{15}$ Hal tersebut tidak berlebihan karena gerejagereja Pentakosta akan melakukan rekonstruksi peristiwa pencurahan Roh Kudus sebagai ciri khas gereja mula-mula yang mereka ikuti. Namun demikian, Kisah Para Rasul, di sisi lain, masih menurut Siahaan, dapat menjadi sebuah dinamisasi dari sang penulis untuk memperlihatkan sisi lain Pentakostalisme yang berkaitan dengan dunia akademis. ${ }^{16}$ Artinya, kitab Kisah Para Rasul ini tidak semata-mata hanya menunjukkan Pentakostalisme sebagai gerakan yang menekankan hal sepihak, yakni pelayanan yang bercirikan fenomena adi kodrati.

Teks Kisah Para Rasul yang digunakan adalah Kisah Para Rasul 2:41-47, sebagai dasar analisis deskriptif yang menunjukkan ciri khas jemaat atau gereja di awal lahirnya. Gereja mula-mula berkembang dengan pesatnya di bawah kepemimpinan para rasul setelah mengalami peristiwa pentakostal di sebuah loteng di Yerusalem. Cara hidup jemaat mulamula yang dikisahkan dalam perikop tersebut menunjukkan indikator pertumbuhan gereja yang pesat pada masa itu, yang mana secara prinsip dapat diterapkan di segala masa, termasuk di masa kini.

Setelah mengetahui metode atau sistem pertumbuhan gereja yang pada umumnya diterapkan oleh para pemimpin gereja yaitu metode atau sistem pertumbuhan gereja sel dan gereja alamiah, maka pada bagian ini penulis ingin menawarkan satu metode atau sistem pertumbuhan gereja yang ada di dalam Kisah para Rasul 2:41-47 yaitu Cara Hidup Jemaat yang Pertama menurut pendapat dan pengalaman penulis dalam membantu mengelola sebuah gereja adalah sebuah metode atau sistem pertumbuhan gereja yang ideal untuk diterapkan karena sangat efisien, efektif dan punya dampak yang besar bagi jemaat yang dilayani atau masyarakat umum yang ikut merasakan dampak pelayanan gereja. Pada ayat-

\footnotetext{
${ }^{15}$ Harls Evan R. Siahaan, "Presuposisi Kitab Kisah Para Rasul Dalam Rancang Bangun Teologi Pentakosta," Kurios 4, no. 1 (April 11, 2018): 56-73, accessed April 20, 2018, http://www.sttpb.ac.id/ejournal/index.php/kurios/article/view/34/48.

${ }^{16}$ Harls Evan R Siahaan, "Merefleksikan Konsep Proto-Logos Lukas Dalam Membangun Dan Meningkatkan Kegiatan Publikasi Ilmiah Di Lingkungan Sekolah Tinggi Teologi," BIA: Jurnal Teologi dan Pendidikan Kristen Kontekstual 1, no. 2 (2018): 138-152, http://www.jurnalbia.com/index.php/bia.
} 
ayat ini penulis Kisah Para Rasul yaitu Lukas ingin menunjukkan suatu gambaran tentang kehidupan kekristenan pada gereja mula-mula. Ada 5 (lima) unsur yang dilakukan oleh jemaat mula-mula yang perlu diketahui oleh para pemimpin gereja masa kini.

\section{Jemaat bertekun dalam pengajaran rasul-rasul (ay 42)}

Kata bertekun diterjemahkan dalam kata Yunani proskarterountes yang berasal dari akar kata proskartereo, yang artinya bertekun, mendampingi, melayani, disamping, menyediakan, memakai banyak waktu, tetap rajin/tekun. Hal ini menerangkan cara mereka yang secara terus menerus belajar banyak waktu untuk menekuni dari pengajaran rasulrasul dengan penuh ketabahan dan kesetiaan. Tanda dari orang yang sudah menerima Yesus dan kepenuhan Roh Kudus, bukan hanya semangat saja tetapi juga bertekun untuk belajar firman Tuhan.

\section{Jemaat bertekun dalam persekutuan (ay 42)}

Kata persekutuan berasal dari kata Yunani koinonia yang menyatakan sekumpulan orang yang memiliki pandangan hidup yang sama dan kepentingan yang sama untuk mewujudkan suatu tujuan yang telah diterapkan. Mereka memiliki pandangan hidup yang sama, bahwa Yesus adalah Tuhan dan Kristus dan mereka juga ingin menikmati persekutuan yang intim dengan Roh Kudus supaya Injil Kerajaan Allah dapat disebarluaskan ke seluruh pelosok dunia (Kis 1:8).

\section{Jemaat memecahkan roti bersama (ay 42, 46)}

Roti merupakan makanan utama bagi masyarakat Yahudi pada saat itu. Memecahkan roti artinya makan bersama. Banyak orang menafsirkan "memecahkan roti" klasei tou artou, pemecahan roti adalah perjamuan kasih yang disertai dengan perjamuan kudus. Yesus sendiri memcahkan roti saat Ia hendak memberi makan 5.000 orang yang mengikutiNya (Mat. 14:19). Ia juga sering melakukan saat Ia bersekutu dengan muridmuridNya (Luk. 24:30). Paulus memecahkan roti ketika bersekutu dengan jemaat Tuhan yang ada di Troas (Kis. 20:7,11) dan juga ketika berlayar di laut Adria (Kis. 27:35). Memecahkan roti mengisyaratkan adanya persaudaraan yang erat, kesamaan, kesatuan dan komunikasi yang harmonis.

\section{Jemaat berdoa dengan sungguh-sungguh (ay 42)}

Kata berdoa berasal dari akar kata Yunani proseuche yang menyatakan adanya aktivitas doa yang bersungguh-sungguh. Doa adalah aktivitas rohani yang "tidak kelihatan" ketika dipanjantkan, tetapi "dapat dirasakan" oleh orang yang berdoa dan hasilnya "dapat dilihat" ketika mendapatkan jawaban dari Allah. Hal ini dialami oleh jemaat mula-mula. Dan setiap kali mereka selesai berdoa mereka selalu menerima hasil doa, bahkan seringkali Allah langsung bergerak menyatakan kuasaNya saat mereka sedan 
berdoa (Kis. 4:24-31; 12:1-19). Jemaat mula-mula dimulai dengan 120 orang yang berdoa (Kis.1:4) dan jemaat berkembang pesat karena peran doa. Doa adalah nafas hidup jemaat mula-mula (Kis. 2:42, 6:4,6). Doa berhubungan dengan Allah langsung melalui kuasa Roh Kudus (Kis. 4:31). Doa bagaikan jembatan emas untuk datang kepada Allah.

\section{Jemaat Memuji Allah (ay 47)}

Kata memuji berasal dari kata Yunani ainountes adalah kata yang dipakai untuk menerangkan keadaan jemaat mula-mula yang sudah memuji Allah. Pujian adalah suatu pernyataan umat Allah akan keanggungan kasih dan kuasa Allah yang dirasakan. Kata ainountes berhubungan erat dengan epainos yang menyatakan oknum yang dipuji memang layak untuk dipuji atau patut untuk dihargai. Berdasarkan pengertian tersebut di atas, nampak beberapa unsur penting dalam pujian yaitu: Subyek Pujian; yaitu umat Allah yang memiliki kesadaran untuk suka memuji Allah; Obyek pujian, yaitu Allah menjadi sasaran tunggal untuk dipuji; Tujuan memuji Allah, adalah menganggungkan Allah dan hanya Allah yang layak untuk dipuji; Pujian itu dinamis, yaitu kuasa Allah yang sangat nyata ketika umatNya memuji Allah. ${ }^{17}$ Dampak dari gaya hidup jemaat mula-mula sangat nyata dalam diri mereka (ay 43, 46-47), yaitu ketakutan, kuasa Tuhan bekerja, kesehatian, disukai semua orang dan mengalami pertumbuhan kuantitas.

Pertama, Kata 'ketakutan” (ay 43) berasal dari bahasa Yunani fobos. Ketakutan adalah dampak awal dari cara hidup jemaat mula-mula. Mereka semua menjadi takut karena melihat para rasul mengadakan tanda-tanda dan mujizat, berarti ini membuktikan bahwa apa yang dikatakan oleh rasul-rasul adalah sesuatu yang diperkenan Allah.

Kedua, Tanda-tanda dan mujizat dari Tuhan (ay 43). Tanda-tanda dan mujizat dari Tuhan sebagai penggenapan janji Bapa kepada umatNya, dinyatakan oleh para rasul, antara mujizat-mujizat yang dilakukan Petrus; (Kis 3:7; 5:5,10,16; 9:34), mujizat-mujizat yang dilakukan Paulus (Kis 13:11; 14:10;16:18; 19:12; 20:10; 28:5; 28;8). Hal ini membuat pemberitaan Injil menjadi sangat efektif dan jumlah yang bertobat meningkat dengan pesat.

Ketiga, Persatuan jemaat (ay 44, 46) dampak ketiga dari gaya hidup jemaat mula-mula adalah persatuan jemaat. Persatuan jemaat ini bukan saja nampak pada keharmonisan hidup bersama tetapi persatuan juga nampak pada "rasa kepemilikan" sebab dikatakan, "segala kepunyaan bersama" (ay 44), kesatuan dalam kepemilikan ini telah mendorong mereka yang mempunyai lebih untuk menjual harta milik mereka dan hasilnya dibagi-bagikan kepada yang membutuhkan.

Keempat, disukai semua orang (ay 47), bukanlah hal ini yang aneh apabila jemaat mula-mula disukai banyak orang, khususnya penduduk Yerusalem, karena mereka

\footnotetext{
${ }^{17}$ Daniel Sutoyo, Suatu Eksegesis Kisah Para Rasul-Seri I, (Surakarta : STT Intheos,2010), 54
} 
menyaksikan sendiri cara hidup jemaat mula-mula yang dipenuhi dengan kasih dan kuasa Allah. Mereka hidup dengan rukun dan saling memperhatikan satu terhadap yang lain.

Kelima, jemaat yang bertumbuh (ay 47). Pertumbuhan jemaat mula-mula, baik pertumbuhan secara kuantitas maupun kualitas. Pertumbuhan secara kuantitas adalah pertambahan jumlah anggota jemaat. Pertumbuhan secara kualitas, adalah pertumbuhan rohani yang menjadi dewasa di dalam Tuhan. Ini berarti jemaat mula-mula selalu mengadakan pertemuan-pertemuan ibadah setiap hari, maka Allah setiap hari selalu menambah-nambahkan jumlah anggota gereja (ay 47). ${ }^{18}$

\section{PEMBAHASAN}

Berangkat dari metoda atau sistem kehidupan jemaat yang pertama atau sering disebut dengan jemaat mula-mula yang ada dalam Kisah para rasul 2:41-47 sebagaimana yang telah dipaparkan di atas, maka implikasinya bagi pertumbuhan gereja masa kini menurut pendapat penulis masih sangat relevan bahkan penulis mendorong agar metode atau sistem ini tetap dipertahankan dengan cara para pemimpin gereja mempraktekan cara hidup jemaat mula-mula tersebut di atas. Setidaknya ada hal-hal yang bisa diusahakan dalam meningkatkan pertumbuhan gereja-gereja masa kini adalah:

\section{Mendorong dan Memfasilitasi Jemaat Untuk Beribadah}

Gereja harus memulai dengan ibadah hari Minggu berapapun jumlah jemaat yang sudah berhasil dikumpulkan maka sedini mungkin jemaat diajak untuk mulai beribadah dan bersekutu pada Tuhan Yesus. Sesuai dengan perjalanan waktu jemaat dapat diarahkan masuk dalam ibadah sesuai kategori usia mereka misalnya ibadah anak-anak (Sekolah Minggu), ibadah remaja, ibadah pemuda, ibadah dewasa muda, ibadah kaum wanita, ibadah kaum pria dan ibadah bagi kaum lanjut usia. Apabila gereja ingin cepat berkembang maka bisa ditambahkan pula ibadah dalam kelompok kecil apapun istilah yang dipakai mau ibadah rumah tangga, kelompok sel atau lainnya. Pastinya cara ini telah menjadi bukti implementasi dari cara hidup jemaat yang pertama yang suka berkumpul bersama untuk bersekutu atau beribadah pada Tuhan Yesus.

\section{Memuridkan jemaat untuk menjadi serupa dengan Kristus}

Jemaat yang ingin bertumbuh dengan ideal tidak hanya dilihat dari bertambahnya jumlah jemaatnya saja, akan tetapi juga akan kualitas jemaat itu juga penting. Kualitas jemaat itu akan terlihat dari bagaimana jemaat itu dewasa dalam iman dan pengajaran Firman Tuhan yang terpancar keluar melalui tutur kata dan perilakunya sehari-hari. Sumiwi mengemukakan bahwa ada proses pembaharuan pikiran yang terjadi terus-menerus setiap waktu melalui Firman Tuhan yang dikerjakan oleh Roh Kudus, sehingga dengan proses ini

\footnotetext{
${ }^{18}$ Ibid, 55
} 
orang Kristen akan mengerti kehendak Allah: apa yang baik, yang berkenan kepada Allah dan sempurna. ${ }^{19}$

Ketika mata hati seseorang diterangi oleh Roh Kudus, maka ia akan bertumbuh dalam pengenalan akan Allah. ${ }^{20}$ Untuk bisa mendapatkan jemaat yang berkualitas maka pemimpin gereja mempunyai tanggung jawab memuridkan jemaatnya melalui kelas-kelas pemuridan bisa dalam bentuk Kelompok Pemahaman Alkitab, bisa dalam bentuk kelas pemuridan Saya Pengikut Yesus, bisa dalam kelas pemuridan Sekolah Orientasi Melayani dan lainlain. Semua usaha pemuridan yang dilakukan oleh pemimpin gereja ini telah menjadi wujud nyata dalam mengimplementasikan kehidupan jemaat yang pertama atau mula-mula dalam hal mereka bertekun dalam pengajaran para rasul.

Pemuridan adalah hal yang penting dalam meneruskan ajaran. Soeliasih mengemukakan bahwa pemuridan Elia kepada Elisa adalah contoh yang baik bagi pendidikan agama Kristen, baik di sekolah maupun di gereja. Prinsip-prinsip dari pelayanannya dapat diterapkan pada masa sekarang. ${ }^{21}$ Selanjutnya Winarno juga mengemukakan bahwa pola pemuridan yang tertulis dalam II Timotius 2:1-3 merupakan strategi yang baik bagi pelipatgandaan gereja. ${ }^{22}$

\section{Mendorong Jemaat untuk Antusias dalam Memuji dan Menyembah Tuhan}

Jemaaat Tuhan perlu sejak sekarang dilatih untuk memiliki gaya hidup penyembahan, karena salah satu aktivitas yang akan dilakukan di surga nanti adalah penyembahan pada Tuhan dalam roh dan kebenaran. Pemimpin gereja dapat menyediakan sarana yang sengaja bisa dipakai oleh jemaat dalam mengekspresikan berdoa dan menyembah Tuhan misalnya ibadah praise and worship, ibadah doa malam dan lain-lain. Cara ini sangat efektif bagi pemimpin gereja dalam mengimplementasikan gaya hidup jemaat yang pertama atau mulamula dalam hal mereka memuji Tuhan.

\section{Membangkitkan dan Melatih Jemaat untuk Senang Mengabarkan Injil}

Untuk mendukung pertumbuhan jemaat yang diharapkan, pemimpin gereja tidak mungkin mengerjakan sendirian semua usahanya tetapi harus melibatkan semua jemaat yang ada dengan cara membangkitkan dan melatih jemaat untuk perduli pada jiwa-jiwa yang belum terselamatkan. Pertama pemimpin harus memotivasi dan membangkitkan

\footnotetext{
${ }^{19}$ Asih Rachmani Endang Sumiwi, "Pembaharuan Pikiran Pengikut Kristus Menurut Roma 12:2" Jurnal Teologi Berita Hidup Vol 1 No. 1, 2018, 46-56.

${ }^{20}$ Joseph Christ Santo, "Makna dan Penerapan Frasa Mata Hati yang Diterangi dalam Efesus 1:18-19" Jurnal Teologi Berita Hidup Vol 1. No. 1, 2018, 1-12.

${ }^{21}$ Soeliasih, "Penerapan Prinsip Pemuridan Elia dalam Pendidikan Agama Kristen" Jurnal Teologi Berita Hidup Vol. 2 No. 1, 2019, 2-10.

${ }^{22}$ Winarno, "Relevansi Strategi Pelipatgandaan Jemaat Berdasarkan 2 Timotius 2: 1-13" Jurnal Teologi Berita Hidup Vol. 1 No. 2, 2019, 90-108
} 
gairanh dalam memberitakan Injil bagi sesama yang paling dekat, misalnya keluarganya atau tetangganya, sahabat, rekan kerja, teman sekolah, teman bermain dan lain sebagainya.

Sekarang ini banyak materi pelatihan penginjilan yang tersedia misalnya Prinsip 4 , Evangelism Explosion, My Home dan lain sebagainya. Kristiono berpendapat bahwa secara demografi telah terjadi pertambahan jumlah pemuda, ini merupakan target yang bagus bagi pelayanan misi di kalangan muda-mudi. ${ }^{23}$ Usaha ini bila dilakukan akan sangat efektif dan efisien dalam menjangkau jiwa-jiwa sehingga gaya hidup jemaat pertama atau mula-mula yang terus menambahkan bilangan orang yang percaya pada Tuhan Yesus akan cepat terwujud.

\section{Melatih Jemaat Berbagi Kehidupan dan Melayani Sesama}

Cara hidup jemaat pertama atau mula-mula yang nampak dan menjadi berkat bagi masyarakat sekitar yang melihatnya adalah gaya hidup yang suka bernagi dan melayani sesama. Gaya hidup ini tidak otomatis terbentuk, namun hal ini harus disediakan wadahnya dan dilakukan pelatihan. Pemimpin gereja memiliki kewajiban untuk menyediakan wadahwadah pelayanan yang relevan dengan kebutuhan masyarakat sekitar dan melatih jemaatnya agar terampil melayani. Sumiwi dan Santo mengemukakan bahwa setiap orang percaya perlu terlibat dalam pelayanan. ${ }^{24}$ Oleh sebab itu perlu dibuat wadah-wadah pelayanan masyarakat misalnya pelayanan kesehatan, pelayanan potong rambut dan pelayanan pembagian atau penjualan sembako bersubsidi, pelayanan bimbingan belajar dan lain-lain.'

Wadah pelayanan ini akan menjadi tempat jemaat menyalurkan kerinduan untuk melayani dan berbagi apa saja yang mereka miliki yaitu doa, daya dan dana. Cara ini juga merupakan cara yang efektif dan efisien dalam mengimplementasikan gaya hidup jemaat yang pertama atau mula-mula dalam hal berbagi hidup dan melayani Tuhandan sesama. Kehidupan jemaat pertama atau jemaat mula-mula bagi penulis merupalan metoda atau sistem pertumbuhan gereja yang ideal untuk diterapkan pada gereja masa kini mengingat metoda ini sangat efektif, efisien dan membawa dampak yang besar baik bagi jemaat itu sendiri ataupun bagi masyarakat yang menyaksikan cara hidup jemaat yang sangat baik ini.

Gereja yang ingin terus bertumbuh tentunya akan mendorong jemaatnya untuk memusatkan perhatiannya pada Tuhan Yesus sebagai Kepala Gereja dengan mematuhi perintah Tuhan Yesus dengan menyarikan seluruh perintah Perjanjian Baru menjadi dua aspek yaitu Kasihilah Tuhan dan kasihilah sesama manusia. Gereja yang ingin terus bertumbuh akan memikirkan, menyusun dan merencanakan sebuah program pelatihan

\footnotetext{
${ }^{23}$ Rahmat Kristiono, "Bonus Demografi Sebagai Peluang Pelayanan Misi Gereja di Kalangan MudaMudi” Jurnal Teologi Berita Hidup, 1 (2), 2019, 174-182.

${ }^{24}$ Asih Rachmani Endang Sumiwi dan Joseph Christ Santo, "Menerapkan Konsep Pelayan Tuhan Perjanjian Baru pada Masa Kini”, EPIGRAPHE: Jurnal Teologi dan Pelayanan Kristiani 3 (2), 2019, 94-106
} 
pemuridan yang akan memperlengkapi setiap jemaatnya terlibat dalam pelayanan yang semakin hari semakin kompleks.

Demikian juga gereja yang ingin bertumbuh harus memperlengkapi jemaatnya dengan kegiatan ibadah dan doa serta memberikan kepercayaaan bersekutu dengan orang-orang yang belum aktif dalam kegiatan gereja sambil dengan aktif menjangkau dan memenangkan mereka kepada Kristus. Pada akhirnya pemimpin gereja juga harus mempraktekan gaya hidup nyata dengan berbagi kehidupan baik kepada warga gerejanya maupun kepada warga masyarkat sekitarnya, melalui pelayanan kasih berupa donor darah, pengobatan gratis, bazar dan lain sebagainya. Segala hal yang dilakukan di atas menjadi bentuk nyata dari implementasi gereja terhadap cara hidup jemaat mula-mula yang akan berdampak bagi pertumbuhan gereja baik secara kuantitas maupun kualitas.

\section{KESIMPULAN}

Pertumbuhan gereja sampai hari ini masih menjadi konsentrasi bagi para pemimpin gereja yang memiliki visi dan misi terhadap pertumbuhan gereja Tuhan yang dilayaninya. Ada banyak metoda atau sistem pertumbuhan gereja yang umum diterapkan oleh pemimpin gereja. Cara hidup jemaat mula-mula yang tercantum dalam Kisah Para Rasul 2:41-47 menjadi salah satu metoda atau sistem pertumbuhan gereja yang menurut penulis masih relevan untuk diterapkan karena sangat efektif, efisien dan berdampak positif. Gereja tinggal merumuskan bentuk-bentuk program gereja sebagai implementasi dari cara hidup gereja mula-mula sehingga dapat mendorong terjadinya pertumbuhan di gereja Tuhan yang dilayaninya.

\section{REFERENSI}

Alkitab, Jakarta LAI , 1996

Daniel Sutoyo, Komunitas Kecil Sebagai Tempat Pembelajaran Gaya Hidup Kristen Solo : Jurnal Antusias, STT Intheos, Vol.II, 2012

Daniel Sutoyo, Suatu Eksegesis Kisah Para Rasul-Seri I Surakarta : STT Intheos,2010

Dep.Komsel GBI Keluarga Allah, SOM Kelas-3 Aku Pasti Berbuah Solo : Divisi Media Cetak El-Shadday Media Production (tp. tth)

Dwiraharjo, Susanto. "Kajian Eksegetikal Amanat Agung Menurut Matius 28 : 18-20." Jurnal Teologi Gracia Deo 1, no. 2 (2019): 56-73. http://sttbaptisjkt.ac.id/ejournal/index.php/graciadeo.

Hartono, Handreas. "Mengaktualisasikan Amanat Agung Matius 28 : 19-20 Dalam Konteks Era Digital." KURIOS (Jurnal Teologi dan Pendidikan Agama Kristen) 4, no. 2 (2018): 19-20. www.sttpb.ac.id/e-journal/index.php/kurios.

Kornelius Sabat, Pertumbuhan Gereja Yogyakarta : Charista Press, 2016

Kristiono, Rahmat. "Bonus Demografi Sebagai Peluang Pelayanan Misi Gereja di Kalangan Muda-Mudi” Jurnal Teologi Berita Hidup, Vol 1 No. 2, 2019.

Peter Wongso, Tugas Gereja dan Misi Masa Kini Malang : SAAT, 1999

Rick Warren, The Purpose Driven Church Malang, Gandum Mas, 2006 
Santo, J.C., "Makna dan Penerapan Frasa Mata Hati yang Diterangi dalam Efesus 1:18-19" Jurnal Teologi Berita Hidup Vol 1. No. 1, 2018, 1-12.

Santo, Joseph Christ, and Dapot Tua Simanjuntak. "Pengaruh Keteladanan Hidup Gembala Sidang Terhadap Pertumbuhan Gereja.” KHARISMATA: Jurnal Teologi Pantekosta 2, no. 1 (2019): 28-41.

Siahaan, Harls Evan R. "Merefleksikan Konsep Proto-Logos Lukas Dalam Membangun Dan Meningkatkan Kegiatan Publikasi Ilmiah Di Lingkungan Sekolah Tinggi Teologi.” BIA: Jurnal Teologi dan Pendidikan Kristen Kontekstual 1, no. 2 (2018): 138-152. http://www.jurnalbia.com/index.php/bia.

Siahaan, Harls Evan R. "Karakteristik Pentakostalisme Menurut Kisah Para Rasul." DUNAMIS ( Jurnal Teologi dan Pendidikan Kristiani ) 2, no. 1 (2017): 12-28. http://www.sttintheos.ac.id/e-journal/index.php/dunamis/article/viewFile/132/116.

_. "Presuposisi Kitab Kisah Para Rasul Dalam Rancang Bangun Teologi Pentakosta." Kurios 4, no. 1 (April 11, 2018): 56-73. Accessed April 20, 2018. http://www.sttpb.ac.id/e-journal/index.php/kurios/article/view/34/48.

Soesilo, Yushak. "Pentakostalisme Dan Aksi Sosial: Analisis Struktural Kisah Para Rasul 2:41-47." DUNAMIS: Jurnal Teologi dan Pendidikan Kristiani (2018).

Soeliasih, "Penerapan Prinsip Pemuridan Elia dalam Pendidikan Agama Kristen" Jurnal Teologi Berita Hidup Vol. 2 No. 1, 2019.

Sumiwi, ARE, "Pembaharuan Pikiran Pengikut Kristus Menurut Roma 12:2” Jurnal Teologi Berita Hidup Vol 1 No. 1, 2018.

Sumiwi, ARE dan Santo, JC "Menerapkan Konsep Pelayan Tuhan Perjanjian Baru pada Masa Kini”, EPIGRAPHE: Jurnal Teologi dan Pelayanan Kristiani 3 (2), 2019, 94106

Winarno, "Relevansi Strategi Pelipatgandaan Jemaat Berdasarkan 2 Timotius 2: 1-13" Jurnal Teologi Berita Hidup Vol. 1 No. 2, 2019.

Yakob Tomatala, Teologi Misi Jakarta : YT Leadership Fondation, 2003

Zaluchu, Sonny Eli. "Eksegesis Kisah Para Rasul 2:42-47 Untuk Merumuskan Ciri Kehidupan Rohani Jemaat Mula-Mula Di Yerusalem." EPIGRAPHE: Jurnal Teologi dan Pelayanan Kristiani 2, no. 2 (2018): 72-82. Accessed November 1, 2018. http://www.stttorsina.ac.id/jurnal/index.php/epigraphe. 